\title{
Vitamin D Deficiency in Children with Chronic Renal Disease
}

\author{
S. B. Dyussenova*, M. Y. Gordiyenko, G. B. Serikova, S. A. Turlybekova, A. A. Issayeva, N. A. Yerimbetova, V. O. Goroshko
}

Department of Pediatrics and Neonatology, NC JSC Medical University of Karaganda, Karaganda, Kazakhstan

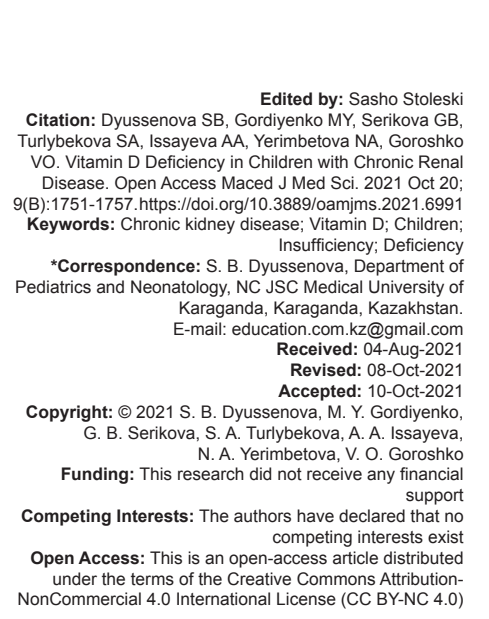

\begin{abstract}
BACKGROUND: Vitamin D is essential for children and adults for healthy bone growth. Lack of this vitamin in children can cause rickets, and in adults, softening of the bones and an increased risk of fractures. Vitamin D deficiency can cause immune disorders, increased susceptibility to infections, the development of certain types of cancer, diabetes mellitus, and cardiovascular diseases.

AIM: The article presents the literature data and the results of our own research on the analysis of the relationship between chronic kidney disease (CKD) and Vitamin D provision in children from 1 to 17 years old. The aim of the study was to establish the level of Vitamin $D$ in children with different stages of CKD.

METHODS: Between January 2020 and September 2020, we examined 40 children (16 boys and 24 girls). The patients' age ranged from 1 to 17 years inclusive.

RESULTS: Vitamin D deficiency was found in $62.5 \%$ of children with CKD. Vitamin D deficiency was noted in $25 \%$ of cases. The prevalence of Vitamin D deficiency correlates with a decrease in glomerular filtration rate.

CONCLUSION: Determination of Vitamin D level in children with CKD is important for timely correction and prevention of further progression of CKD. Timely substitution therapy will improve the quality of life of a child with $\mathrm{CKD}$ and prevent the development of complications.
\end{abstract}

\section{Introduction}

Many people know that Vitamin $D$ is essential for children and adults for healthy bone growth. Lack of this vitamin in children can cause rickets, and in adults, softening of the bones and an increased risk of fractures. Modern scientific research associates vitamin $\mathrm{D}$ deficiency with immune disorders, increased susceptibility to infections, the development of certain types of cancer, diabetes mellitus and cardiovascular diseases (CVD). Vitamin D also plays a very important role in the regulation of reproductive processes in both women and men.

There are two forms of Vitamin D. In humans, up to $90 \%$ of Vitamin D3, or cholecalciferol, is formed in the skin under the influence of ultraviolet rays. Vitamin D2, or ergocalciferol, and partly cholecalciferol enter the human body with animal and plant foods, providing about $10-20 \%$ of the total amount of Vitamin D. Then, they undergo transformation first in the liver, and then in the kidneys to turn into active Vitamin D, calcitriol (CT), which does the main job. It is also worth noting that Vitamin D, being fat-soluble, accumulates in the liver and adipose tissue. With its excess, symptoms of hypervitaminosis D may develop - convulsions in children, calcium deposition in organs and tissues, and the formation of kidney stones. The daily intake of this vitamin is $400-800 \mathrm{IU}$, depending on age. To confirm the lack of Vitamin D in the body, a blood test for Vitamin $D$ is used, while the level of $30-100 \mathrm{ng} / \mathrm{ml}$ is considered to be the norm. Let's make a reservation right away, the norms differ in different countries and even in different laboratories. Deficiency can be indirectly confirmed by determining the level of calcium, phosphorus, and the enzyme alkaline phosphatase in the blood, as well as calcium and phosphorus in the urine. Newborns and infants are a special risk group. In the $1^{\text {st }}$ months of life, the child is actively growing and developing, so even healthy children need additional intake of Vitamin $\mathrm{D}$ to prevent rickets. Moreover, breastfed children suffer due to a deficiency of Vitamin $D$ in a nursing mother. Therefore, the optimal prevention of rickets will be breastfeeding in combination with additional administration of Vitamin D.

Unfortunately, very few foods contain Vitamin D. These are egg yolks, beef liver, and some fish and seafood in which it is found in small quantities such as salmon, sardines, mackerel, cod liver, tuna, and swordfish. The richest in Vitamin $D$ is fish oil made from cod liver. Obviously, nature intended that you get this vitamin through exposure to the sun and to a lesser extent from food sources. Vegetables do not contain Vitamin D at all, so there are no natural sources of this 
vitamin for vegetarians. In many parts of the world, the main food sources of Vitamin D are milk and dairy products, margarine and vegetable oils fortified with Vitamin D; in 17 countries of the world, it is mandatory to enrich margarine with this vitamin. Such products containing biologically active additives form the basis of therapeutic and prophylactic nutrition used to prevent bone loss.

It should be noted that the absorption of Vitamin $D$ in the intestine significantly depends on the presence of other substances (fats and bile acids). It also depends on the type of human nutrition. Deficiency of bile acids leads to impaired absorption of Vitamin D. It is important to understand that some foods make it difficult and even block the absorption of Vitamin D. These include margarine, mayonnaise, fried bacon, sausage with fat, pork fat, fatty cakes, and pastries.

Deficiency of the active form of Vitamin D CT is determined in the early stages of chronic kidney disease (CKD) and progresses as the glomerular filtration rate decreases due to a decrease in its synthesis in the proximal tubules. Decreased CT level is a consequence of CKD and the same time accelerates its progression [1]. Vitamin D plays an important role in many metabolic processes in the human body. In recent years, interest in the extraosseous effects of Vitamin D has increased, since a number of studies has revealed an association of its low values with an increased risk of some extraskeletal pathologies, including certain types of cancer, infections, autoimmune diseases, CVD, and mental disorders as well as kidney disease. Receptors for active metabolites of Vitamin $D$ are present in most cells and tissues of the body, which also indicates the participation of Vitamin $D$ in the regulation of various biological functions [2]. Vitamin D, obtained from food and in the form of dietary supplements, as well as formed by exposure to the sun, is biologically inert. To activate and convert the hormone [1,25 $(\mathrm{OH}) 2 \mathrm{D}]$ into the active form of Vitamin $\mathrm{D}$, the body must undergo two hydroxylation processes. The first step of hydroxylation occurs in the liver and converts Vitamin $\mathrm{D}$ to 25 hydroxyvitamin $\mathrm{D}$ [25 (OH) D], also known as calcidiol. The second stage of hydroxylation occurs mainly in the kidneys (with the participation of the enzyme CYP27B1-1 $\alpha$-hydroxylase), and its result is the synthesis of the physiologically active D-hormone, 1,25-dihydroxyvitamin D [1,25 (OH) 2D] [3]. Blood levels of CT are mainly determined by the activity of CYP27B1 in the kidney, under the control of parathyroid hormone, and tightly regulated by negative feedback, which is closed by inhibition of CYP27B1 by high concentrations of CT itself and fibroblast growth factor 23 (FGF23). The stimulation of the enzyme CYP24A1 (24 hydroxylase) helps to limit the formation of the active form of the vitamin, which converts CT into an inactive, water-soluble form of calcitroic acid, which is subsequently excreted from the body with bile. FGF23 is secreted primarily by osteocytes, that is, bone tissue promotes the activation of 24-hydroxylase in response to high concentrations of $D$ hormone and an increase in the concentration of phosphorus in the blood [4]. Serum concentration $25(\mathrm{OH}) \mathrm{D}$ is the best indicator of Vitamin D status, as it reflects the total amount of Vitamin D produced in the skin and obtained from food and nutritional supplements (Vitamin D as a single drug or multivitamin and vitamin-mineral complexes), and has a fairly long half-life in blood - about 15 days [5].

Vitamin D deficiency, as defined by $25(\mathrm{OH})$ D levels of $<30 \mathrm{ng} / \mathrm{ml}$ or $<20 \mathrm{ng} / \mathrm{ml}$, is widespread throughout the world.

At present, the deficiency, and to a greater extent the deficiency of $25(\mathrm{OH}) \mathrm{D}$, is a pandemic, affecting the overwhelming part of the general population, including children and adolescents [6].

The Vitamin $\mathrm{D}$ receptor is the main mediator of the biological action of Vitamin D. Vitamin $D$ receptors are present in almost all tissues of the human body, which suggests that the functions of all cells are impossible without Vitamin D.

Today, many processes are associated with the metabolism of Vitamin D. Vitamin D has crossed the boundaries of $\mathrm{Ca}$ and phosphate metabolism and has become a factor in ensuring the most important physiological functions. It can be considered as a steroid hormone with endocrine, paracrine, and autocrine effects.

Around the world, studies are being conducted to determine the level of Vitamin $\mathrm{D}$ in children with CKD, including in patients after transplantation. It has been found that from $30 \%$ to $50 \%$ of children with CKD are deficient in Vitamin D [7]. In accordance with international recommendations, Vitamin $D$ deficiency is determined when the level of $25(\mathrm{OH}) \mathrm{D}$ in the blood is $<20 \mathrm{ng} / \mathrm{ml}$. The prevalence of Vitamin $\mathrm{D}$ deficiency in children with CKD varies from $40 \%$ to $83 \%$ [18], [19], [20].

Regardless of the underlying cause, CKD is a clinical syndrome characterized by a gradual loss of renal function over time [21]. In particular, the kidney disease: Improving global outcomes (KDIGO) guidelines defines CKDas impairmentofkidney structure or function observed for more than 3 months with health consequences. This definition was formulated for the adult population, where CKD is a common and well-known health problem, but the KDIGO guidelines for definition and setting are not fully applicable to the pediatric population.

Indeed, childhood CKD has clinical features that are specific to childhood, such as the effect of the disease on growth. In addition, some typical characteristics of childhood CKD, such as etiology or cardiovascular complications, are variables that affect the patient's health. This influence is often underestimated, but should not be neglected.

In addition, CKD has a profound psychosocial impact on both the patient and the family. Parents of children with CKD have to perform many tasks [22], [23], [24], [25], [26]. 
According to the KDIGO guidelines, CKD is defined by the presence of structural or functional kidney damage, or by a decrease in the glomerular filtration rate below $60 \mathrm{ml} / \mathrm{min} / 1.73 \mathrm{~m}^{2}$ for more than 3 months. Hence, the term CKD defines renal dysfunction as a continuum rather than a discrete change in renal function. This complicates the study of the prevalence of CKD. Moreover, existing epidemiological data on CKD may underestimate its actual incidence and prevalence, since CKD is often clinically asymptomatic, especially in the early stages. This is partly a result of the lack of a common definition of CKD and a clear classification of its severity, which has recently, at least in part, been defined by the introduction of the KDIGO guidelines. For all of these reasons, most CKD studies include patients with moderate to severe CKD and end-stage renal disease. It should also be noted that such studies are not populationbased. In addition, CKD registries in children are usually limited to small populations [27], [28], [29], [30], [31].

In contrast to adults, in whom diabetes mellitus and arterial hypertension are the predominant causes of CKD, congenital diseases are characteristic of childhood. It is now known that the development of CKD in children is facilitated by genetic, endogenous, demographic (gender and age), and a complex of exogenous factors.

The aim of our study is to establish the level of Vitamin D in children with different stages of CKD. An additional goal of the study is to study clinical and laboratory parameters and Vitamin D levels in children with CKD.

\section{Materials and Methods}

The study of the level of Vitamin D was carried out in children with CKD stages 1-5. Children were treated at the Nephrology Department of the Regional Children's Clinical Hospital in Karaganda from January 2020 to September 2020. Of these, 16 children $(40 \%)$ are boys and $24(60 \%)$ are girls. The age of the patients is from 1 to 17 years inclusive. Inclusion criteria were the presence of CKD stages 1-5. Limitations of the study: Patients' age $<1$ year and older than 17 years refusal to participate in the study.

CKD was diagnosed according
to the KDIGO criteria (2012) [8]. Stage 1: GFR $\geq 90 \mathrm{ml} / \mathrm{min} / 1.73 \mathrm{~m}^{2}$, stage 2: GFR 89-60 ml/min $/ 1.73 \mathrm{~m}^{2}$; stage $3:$ GFR $59-30 \mathrm{ml} / \mathrm{min} / 1.73 \mathrm{~m}^{2}$; stage 4: GFR $29-15 \mathrm{ml} / \mathrm{min} / 1.73 \mathrm{~m}^{2}$; and stage 5 : GFR $<15 \mathrm{ml} / \mathrm{min} / 1.73 \mathrm{~m}^{2}$.

Using the modified Schwarz formula, the glomerular filtration rate was determined. The level of Vitamin D 25-OH was determined using ELISA. When assessing the level of Vitamin $D$, we were guided by international recommendations [9], [10].

\section{Results and Discussion}

In 2020,523 patients were admitted to the nephrology department of the Regional Children's Clinical Hospital in Karaganda. Of these, there are 83 glomerular diseases, and 440 children with urinary tract infections.

The prevalence of CKD in the world is quite high. In the Netherlands, stages 1-5 CKD are 17.6\%, in the United States stages $1-5 \mathrm{CKD}$ are $15 \%$, and stages $3-5$ are $8.1 \%$. In Spain, $12.7 \%$ of the population suffer from stages 1 to 5 CKD. In Australia, $13.4 \%$ of patients are with CKD, $7.7 \%$ of them at stages $3-5$. In China, this parameter reaches $14 \%$, and in Japan, patients with stages $3-5$ are $18.7 \%$. In Norway, statistics indicate that $10.2 \%$ of people have stages $1-4$ CKD.

We have studied groups of risk factors that affect the development and course of CKD in children:

- $\quad$ A burdened family history - the presence of CKD in $64 \%$ of children in relatives (mom, dad, uncle, aunt, etc.);

- The social status and educational level of the family are low - in $35 \%$ of children;

- $\quad$ Low birth weight or prematurity $-32 \%$;

Factors influencing the development of CKD:

The number of nephrons directly correlates with birth weight; thus, these children have a low number of nephrons and abnormal glomeruli, which leads to hyperfiltration of the remaining glomeruli, proteinuria, and chronic renal failure in the long-term period [9].

Risk factors that initiate CKD:

- Neurogenic bladder dysfunction - $21 \%$ of children;

- The presence of type I and II diabetes mellitus in $15 \%$ of children;

- Infections of the urinary system against the background of vesicoureteral reflux $-10 \%$ of children;

- Urolithiasis - 6\%. authors [32];

Our data are consistent with those of other

- History of hypertension $-45 \%$ of children;

- $\quad$ Autoimmune diseases $-11 \%$ of children;

- $\quad$ Toxic effects of drugs in $9 \%$ of children;

- Hemolytic uremic syndrome in $4 \%$ of children.

Risk factors that lead to the progression of

CKD:

Genetic - familial cases of CKD indicate the existence of a genetic predisposition to progressive nephropathy; Numerous studies suggest a link between CKD and certain variants (polymorphisms) of genes encoding various mediators of CKD progression, 
including components of the renin-angiotensinaldosterone system;

- Violation of urodynamics;

- High degree of proteinuria (increased proteinuria leads to toxic effects on podocytes and impairment of their function);

- Hypertension aggravates hyperperfusion and hyperfiltration in the preserved nephrons;

- Inadequate control of hyperglycemia, participation of metabolic factors (lipiduria, leptinemia, etc.) [33].

It was found that in $62.5 \%$ of cases in children with CKD, Vitamin D deficiency was detected in $25 \%$ of cases.

The average level of $25(\mathrm{OH}) \mathrm{D}$ in the blood plasma was $32.6 \pm 9.2 \mathrm{ng} / \mathrm{ml}$ for all examined patients. Vitamin $D$ levels did not differ between boys (33.7 $\pm 10 \mathrm{ng} / \mathrm{ml}$ ) and girls $(31.7 \pm 8.4 \mathrm{ng} / \mathrm{ml})$. Vitamin $D$ deficiency was detected in $26(65 \%)$ people, lack- in eight children (20\%). There were no differences in the level of $25(\mathrm{OH}) \mathrm{D}$ between age groups in boys (5-9 years old $33.5 \pm 8.5,10-13$ years old $31.5 \pm$ 8.5 , and $14-17$ years old $36.5 \pm 12.7 \mathrm{ng} / \mathrm{ml}$ ). Among girls, a significant decrease was revealed in the age group 14-17 years old (5-9 years old $-35.9 \pm 8.8$ and $10-13-30.1 \pm 6.6,14-17-27.8 \pm 7.7 \mathrm{ng} / \mathrm{ml})(\mathrm{p} 5-9 / 14$ $17<0.05)$.

We have also determined Vitamin $D$ levels in children with CKD. There were no differences in the level of $25(\mathrm{OH}) \mathrm{D}$ between CKD stage 1 and CKD stage 2 (CKD1 - 23.5 \pm 5.5 , CKD $2-21.5 \pm 5.5$, and CKD stage $3-16.5 \pm 2.7 \mathrm{ng} / \mathrm{ml})$. With a decrease in GFR, a significant decrease in the level of $25(\mathrm{OH}) \mathrm{D}$ total was revealed (CKD $4-15.9 \pm 3.8$, CKD $5-10.1 \pm$ 1.6, ng/ml) (CKD 3 - CKD4 - CKD5 < 0.05).

When analyzing statistically significant correlations in children of the main group, there is a strong direct relationship between the level of Vitamin D and GFR and the level of Vitamin D and the stage of CKD. The results obtained in our study also indicated the relationship between clinical signs and the level of Vitamin D. A naturally strong inverse relationship was found between the level of Vitamin D and arterial hypertension, sweating, irritability, edema, fatigue, and decreased appetite. Correlation analysis showed a moderate inverse relationship between Vitamin D levels and laboratory parameters such as proteinuria and urinary syndrome. There is also a weak inverse relationship between Vitamin $D$ scores and comorbidities. These factors show the relationship between the level of Vitamin D and the progression of kidney disease.

When analyzing statistically significant correlations in children of the control group, there is also a strong direct relationship between the level of Vitamin D and GFR and the level of Vitamin D and the stage of CKD. Correlation analysis showed a moderate inverse relationship between the level of Vitamin D and such clinical manifestations as edema, irritability, fatigue, arterial hypertension, and decreased appetite. In the control group, there was a weak inverse relationship between Vitamin $\mathrm{D}$ and concomitant diseases. There is an inverse relationship between the level of vitamin $D$ and laboratory parameters: Hematuria, proteinuria, and urinary syndrome. In conclusion of the analysis of correlations, there is a strong direct correlation between the level of Vitamin D and GFR and the level of Vitamin $D$ and CKD, which confirms the need for early diagnosis and correction of the level of Vitamin $\mathrm{D}$ and will allow early prevention of the progression of kidney disease.

Table 1: Vitamin $D$ deficiency in children with chronic renal disease (\%) and Vitamin D levels

\begin{tabular}{lll}
\hline Vitamin D levels & Parameter in $\mathrm{ng} / \mathrm{ml}$ & Parameter in \% \\
\hline Vitamin D deficiency & $<20 \mathrm{ng} / \mathrm{ml}$ & 62.5 \\
Lack of Vitamin D & $20-29 \mathrm{ng} / \mathrm{ml}$ & 25 \\
Vitamin D norm & $\leq 30 \mathrm{ng} / \mathrm{ml}$ & 12.5 \\
\hline
\end{tabular}

When analyzing qualitative indicators using the Z-criterion, children with CKD with Vitamin D deficiency and children with CKD without Vitamin D deficiency were significantly more frequent (Tables 1 and 2):

- $\quad$ Arterial hypertension in the main group - 58\% compared with the control group - 16\%,

- Urinary syndrome in the main group - $66 \%$ and in the control group - $18 \%$,

- $\quad$ Edema in the main group occurred in $77 \%$ and in the control group in 33\%,

Sweating in children of the main group - 83\% and control group - 29\%,

Proteinuria in children of the main group - $80 \%$ and control group - $31 \%$,

Irritability in the main group $-83 \%$ and control group $-24 \%$.

It was statistically significant:

- Increase in body temperature in children of the main group $-77 \%$ and control group $-35 \%$ of cases,

- $\quad$ Fatigue in the main group $-86 \%$ of children and in the control group - $29 \%$,

Frequent urination in the main group was found in $61 \%$ of children, in the control group was found in $31 \%$ of the studied.

The relationship between the factorial and effective characteristics is statistically significant at a significance level of $p<0.05$.

Table 2: Vitamin D deficiency in children with chronic renal disease (absolute number)

\begin{tabular}{llll}
\hline Stages of CKD & Vitamin D deficiency & Lack of Vitamin D & Vitamin D norm \\
\hline CKD stage 1 & & & \\
CKD stage 2 & 20 children & 5 children & 3 children \\
CKD stage 3 & 5 children & 5 children & 2 children \\
CKD stage 4 & & & \\
CKD stage 5 & & & \\
\hline CKD: Chronic kidney disease. &
\end{tabular}


Table 3: Statistically significant correlations of laboratory and clinical indicators of children of the main group

\begin{tabular}{|c|c|c|c|c|}
\hline Specifications & Criterion name & Criterion value & a-level & p-level \\
\hline Vitamin D, ng/ml and CKD Stage & Spearman coefficient & 0.7 & 0.05 & $p<0.05$ \\
\hline Vitamin D, $\mathrm{ng} / \mathrm{ml}$ and GFR $\mathrm{ml} / \mathrm{min}$ & Spearman coefficient & 0.8 & 0.05 & $p<0.05$ \\
\hline Vitamin D index, $\mathrm{ng} / \mathrm{ml}$ and proteinuria & Spearman coefficient & -0.5 & 0.05 & $p<0.05$ \\
\hline Vitamin $\mathrm{D}$ index, $\mathrm{ng} / \mathrm{ml}$ and urinary c-m & Spearman coefficient & -0.4 & 0.05 & $p<0.05$ \\
\hline Vitamin $\mathrm{D}, \mathrm{ng} / \mathrm{ml}$ and hematuria & Spearman coefficient & -0.4 & 0.05 & $p<0.05$ \\
\hline Vitamin $\mathrm{D}$ index, $\mathrm{ng} / \mathrm{ml}$ and edema & Spearman coefficient & -0.6 & 0.05 & $p<0.05$ \\
\hline Vitamin $\mathrm{D}, \mathrm{ng} / \mathrm{ml}$ and comorbidities & Spearman coefficient & -0.3 & 0.05 & $p<0.05$ \\
\hline Vitamin $\mathrm{D}$ index, $\mathrm{ng} / \mathrm{ml}$ and $\mathrm{AH}$ & Spearman coefficient & -0.7 & 0.05 & $p<0.05$ \\
\hline Vitamin $\mathrm{D}$ index, $\mathrm{ng} / \mathrm{ml}$ and perspiration & Spearman coefficient & -0.8 & 0.05 & $p<0.05$ \\
\hline Vitamin $\mathrm{D}$ index, $\mathrm{ng} / \mathrm{ml}$ and fatigue & Spearman coefficient & -0.6 & 0.05 & $p<0.05$ \\
\hline Vitamin $\mathrm{D}$ index, $\mathrm{ng} / \mathrm{ml}$ and irritability & Spearman coefficient & -0.6 & 0.05 & $p<0.05$ \\
\hline Vitamin $\mathrm{D}, \mathrm{ng} / \mathrm{ml}$ and decreased appetite & Spearman coefficient & -0.5 & 0.05 & $p<0.05$ \\
\hline
\end{tabular}

In patients with CKD, the decrease in Vitamin $\mathrm{D}$ levels is due to increased filtration in the glomeruli and loss of megalin in the proximal tubules. Low substrate levels in patients with CKD may be a result of low sun exposure, low protein diets, and proteinuria [15], [16]. These factors often accompany CKD, leading to the loss of Vitamin D-binding protein in the urine (Tables 3 and 4).

Levels of total and ionized calcium, as well as ionized magnesium and $25(\mathrm{OH}) \mathrm{D}$, did not differ between children with CKD. However, as children grow older, there is a decrease in the excretion of phosphorus in the urine, which reflects the ratio of phosphorus and creatinine in the urine and can be used as a criterion for hyperphosphatemia $\left(95^{\text {th }}\right.$ percentile in children with CKD $1-1.6$, in children with CKD 2 $-1,23$ and with CKD stage $3-1.1$ ). There has also been a decrease in normal plasma phosphorus levels with the onset of puberty. The highest $\beta$-Cross Laps values were found in the prepubertal period, which is apparently associated with a high rate of bone turnover.

Vitamin D plays a very important role in bone and mineral metabolism. Its active form is synthesized mainly in the kidneys, but it can also be formed in the prostate gland, mammary glands, cells of the immune system (macrophages), smooth muscle cells, cells of the pancreas, gastrointestinal tract, and skin under the action of an enzyme $1 \alpha$-hydroxylase. Extrarenal synthesis determines its autocrine and paracrine actions, such as stimulation of cell proliferation and differentiation, as well as regulation of immune activity [11], [12].

It is important to note that Vitamin $\mathrm{D}$ deficiency in children and adolescents occurs in the healthy population in $20-25 \%$ of cases [13], [14].

\section{Conclusion}

The results of this study demonstrate that Vitamin $\mathrm{D}$ deficiency is common in children with CKD. Determining the level of Vitamin $D$ in children with CKD is important for the timely correction and prevention of further progression of CKD. Timely, substitution therapy will improve the quality of life of a child with CKD and prevent the development of complications.

Strengths of the study: The analysis of the relationship between the level of Vitamin $D$ and indicators of the functional state of the kidneys was carried out. The prognostic significance of Vitamin D in the development and progression of renal pathology in children was evaluated. When analyzing statistically significant correlations in children of the main group, there is a strong direct relationship between the level of Vitamin D and GFR and the level of Vitamin D and the stage of CKD. The results obtained in our study also indicated a relationship between clinical signs and Vitamin D levels. A naturally strong inverse relationship was found between the level of Vitamin $D$ and arterial hypertension, sweating, irritability, edema, fatigue, and decreased appetite. Correlation analysis showed a moderate inverse relationship between Vitamin D levels and laboratory parameters such as proteinuria and urinary syndrome. There is also a weak inverse relationship between Vitamin $D$ scores and comorbidities. These factors show the relationship between the level of Vitamin $D$ and the progression of kidney disease.

When analyzing statistically significant correlations in children of the control group, there is also a strong direct relationship between the level of Vitamin D and GFR and the level of Vitamin D and the stage of

Table 4: Statistically significant correlations between laboratory and clinical indicators of children in the control group

\begin{tabular}{|c|c|c|c|c|}
\hline Specifications & Criterion name & Criterion value & a-level & p-level \\
\hline Vitamin D, ng/ml and CKD Stage & Spearman coefficient & 0.6 & 0.05 & $p<0.05$ \\
\hline Vitamin D, $\mathrm{ng} / \mathrm{ml}$ and GFR $\mathrm{ml} / \mathrm{min}$ & Spearman coefficient & 0.6 & 0.05 & $p<0.05$ \\
\hline Vitamin D index, $\mathrm{ng} / \mathrm{ml}$ and proteinuria & Spearman coefficient & -0.3 & 0.05 & $p<0,05$ \\
\hline Vitamin $\mathrm{D}$ index, $\mathrm{ng} / \mathrm{ml}$ and urinary $\mathrm{c}-\mathrm{m}$ & Spearman coefficient & -0.2 & 0.05 & $p<0.05$ \\
\hline Vitamin $\mathrm{D}, \mathrm{ng} / \mathrm{ml}$ and hematuria & Spearman coefficient & -0.2 & 0.05 & $p<0.05$ \\
\hline Vitamin D index, $\mathrm{ng} / \mathrm{ml}$ and edema & Spearman coefficient & -0.5 & 0.05 & $p<0.05$ \\
\hline Vitamin $\mathrm{D}, \mathrm{ng} / \mathrm{ml}$ and comorbidities & Spearman coefficient & -0.3 & 0.05 & $p<0.05$ \\
\hline Vitamin $\mathrm{D}$ index, $\mathrm{ng} / \mathrm{ml}$ and $\mathrm{AH}$ & Spearman coefficient & -0.4 & 0.05 & $p<0.05$ \\
\hline Vitamin $\mathrm{D}$ index, $\mathrm{ng} / \mathrm{ml}$ and perspiration & Spearman coefficient & -0.6 & 0.05 & $p<0.05$ \\
\hline Vitamin $\mathrm{D}$ index, $\mathrm{ng} / \mathrm{ml}$ and fatigue & Spearman coefficient & -0.5 & 0.05 & $p<0.05$ \\
\hline Vitamin $\mathrm{D}$ index, $\mathrm{ng} / \mathrm{ml}$ and irritability & Spearman coefficient & -0.5 & 0.05 & $p<0.05$ \\
\hline Vitamin $\mathrm{D}, \mathrm{ng} / \mathrm{ml}$ and decreased appetite & Spearman coefficient & -0.4 & 0.05 & $p<0.05$ \\
\hline
\end{tabular}


CKD. Correlation analysis showed a moderate inverse relationship between the level of Vitamin $D$ and such clinical manifestations as edema, irritability, fatigue, arterial hypertension, and decreased appetite. In the control group, there was a weak inverse relationship between Vitamin D and concomitant diseases. There is an inverse relationship between the level of Vitamin D and laboratory parameters: Hematuria, proteinuria, and urinary syndrome. In conclusion of the analysis of correlations, there is a strong direct correlation between the level of Vitamin D and GFR and the level of Vitamin $D$ and $C K D$, which confirms the need for early diagnosis and correction of the level of vitamin $D$ and will allow early prevention of the progression of kidney disease.

\section{References}

1. Smirnov $\mathrm{AV}$, Volkov MM. The role of Vitamin $\mathrm{D}$ in slowing the progression of chronic kidney disease. Nephrology. 2008;4: 20-7. Available from: https://www.cyberleninka.ru/article/n/ rol-vitamina-d-v-zamedlenii-progressirovaniya-hronicheskoybolezni-pochek. [Last accessed on $2021 \mathrm{Jul}$ 25].

2. Maltsev SV, Mansurova GS. Vitamin D metabolism and ways of implementing its main functions. PM. 2014;9:85. Available from: https://www.cyberleninka.ru/article/n/metabolizm-vitamina-d-i-putirealizatsii-ego-osnovnyh-funktsiy. [Last accessed on 2021 Jul 25].

3. Institute of Medicine, Food and Nutrition Board. Dietary Reference Intakes for Calcium and Vitamin D. Washington, DC: National Academy Press; 2010.

4. Kalinchenko SY, Pigarova EA, Gusakova DA, Plescheva AV. Vitamin D and urolithiasis. Consilium Med. 2012;12(14):97-102.

5. Pludowski P, Holick MF, Pilz S, Wagner CL, Hollis BW, Grant WB, et al. Vitamin D effects on musculoskeletal health, immunity, autoimmunity, cardiovascular disease, cancer, fertility, pregnancy, dementia and mortality-a review of recent evidence. Autoimmun Rev. 2013;12(10):976-89. https://doi.org/1016/j. autrev.2013.02.004 PMid:23542507

6. Mithal A. Treatment of Vitamin D Deficiency. Endocrine Case Management ICE/ENDO 2014 Meet-the-Professor, Endocrine Society; 2014. p. 37-9

7. Petrosyan EK, Molchanova MS, Pankratenko TE, Valov AL, Abdullaev FK, Goldyreva NG, et al. Calcidiol in children with stage 2-5 chronic kidney disease. Nephrology. 2018;22(3):5864. https://doi.org/10.24884/1561-6274-2018-22-3-58-64

8. Delucchi A, Alarcón C, Cano F, Lillo AM, Guerrero JL, Azócar $\mathrm{M}$, et al. Hypovitaminosis $\mathrm{D}$ in pediatric patients on renal replacement therapy. Rev Med Chil. 2011;139(3):334-9.

9. Eknoyan G, Lameire N, Eckardt K, Kasiske B, Wheeler D, Levin A, et al. KDIGO 2012 clinical practice guideline for the evaluation and management of chronic kidney disease. Kidney Int Suppl. 2013;3:1-150. Available from: http://www.kdigo.org/ clinical_practice_guidelines/pdf/ckdkdigo_2012_ckd_gl.pdf [Last accessed on $2021 \mathrm{Jul} 25]$.

10. Langman CB, Salusky IB, Greenbaum L, Jueppner H, Leonard M, Nelson P, et al. KDOQI clinical practice guidelines for bone metabolism and disease in children with chronic kidney disease: Work group membership. Am J Kidney Dis. 2005;46 Suppl 1:S1-122.

11. KDOQI Work Group. KDOQI clinical practice guideline for nutrition in children with CKD: 2008 update. Executive summary. Am J Kidney Dis. 2009;53 Suppl 3:S11-104. https:// doi.org/10.1053/j.ajkd.2008.11.017

PMid:19231749

12. Chesney RW. Interactions of Vitamin $D$ and the proximal tubule. Pediatr Nephrol. 2016;31(1):7-14. https://doi.org/10.1007/ s00467-015-3050-5

PMid:25618772

13. Damasiewicz M, Kerr PG, Polkinghorne KR. Vitamina D therapy in chronic kidney disease: Back to the future? Clin Nephrol. 2015;84(2):65-74. https://doi.org/10.5414/CN108519 PMid:26152127

14. Mansbach JM, Ginde AA, Camargo CA Jr. Serum 25-hydroxyvitamin D levels among US children aged 1 to 11 years: Do children need more Vitamin D? Pediatrics. 2009;124(5):1404-10. https://doi.org/10.1542/peds.2008-2041 PMid:19951983

15. Saintonge $\mathrm{S}$, Bang $\mathrm{H}$, Gerber LM. Implications of a new definition of Vitamin D deficiency in a multiracial US adolescent population: The national health and nutrition examination survey III. Pediatrics. 2009;123(3):797-803. https:// doi.org/10.1542/peds.2008-1195 PMid: 19255005

16. Płudowski P, Karczmarewicz E, Bayer M, Carter G, ChlebnaSokół D, Czech-Kowalska J, et al. Practical guidelines for the supplementation of Vitamin $D$ and the treatment of deficits in Central Europe-recommended Vitamin D intakes in the general population and groups at risk of Vitamin D deficiency. Endokrynol Pol. 2013;64(4):319-27. https://doi.org/10.5603/ep.2013.0012 PMid:24002961

17. Cho HY, Hyun HS, Kang HG, Ha IS, Cheong HI. Prevalence of $25(\mathrm{OH})$ Vitamin $D$ insufficiency and deficiency in pediatric patients on chronic dialysis. Perit Dial Int. 2013;33(4):398-404. https://doi.org/10.3747/pdi.2011.00246 PMid:23209039

18. Dibas BI, Warady BA. Vitamin D status of children receiving chronic dialysis. Pediatr Nephrol. 2012;27(10):1967-73. https:// doi.org/10.1007/s00467-012-2203-z PMid:22660955

19. Hari P, Gupta N, Hari S, Gulati A, Mahajan P, Bagga A. Vitamin D insufficiency and effect of cholecalciferol in children with chronic kidney disease. Pediatr. Nephrol. 2010;25(12):2483-8. https:// doi.org/10.1007/s00467-010-1639-2 PMid:20872152

20. Becherucci F, Roperto RM, Materassi M, Romagnani P. Chronic kidney disease in children. Clin Kidney J. 2016;9(4):583-91. https://doi.org/10.1093/ckj/sfw047

PMid:27478602

21. Brück K, Stel VS, Fraser S, De Goeij MC, Caskey F, AbuHanna A, et al. Translational research in nephrology: Chronic kidney disease prevention and public health. Clin Kidney J. 2015;8(6):647-55. https://doi.org/10.1093/ckj/sfv082 PMid:26613019

22. Saran R, Li Y, Robinson B, Ayanian J, Balkrishnan R, BraggGresham J, et al. US renal data system 2014 annual data report: Epidemiology of kidney disease in the United States. Am J Kidney Dis. 2015;66 Suppl 1:S7, S1-305. https://doi. org/10.1053/j.ajkd.2015.05.001 PMid:26111994

23. VivanteA, HildebrandtF. Exploring the genetic basis of early-onset chronic kidney disease.Nat Rev Nephrol. 2016;12(3):133-46. https://doi.org/10.1038/nrneph.2015.205. PMid:26750453

24. Ding W, Cheung WW, Mak RH. Impact of obesity on kidney function and blood pressure in children. World J Nephrol. 
2015;4:223-9. https://doi.org/10.5527/wjn.v4.i2.223 PMid:25949935

25. Dummer PD, Limou S, Rosenberg AZ, Heymann J, Nelson G, Winkler CA, et al. APOL1 kidney disease risk variants: An evolving landscape. Semin Nephrol. 2015;35(3):222-36. https:// doi.org/10.1016/j.semnephrol.2015.04.008 PMid:26215860

26. Giglio S, Provenzano A, Mazzinghi B, Becherucci F, Giunti L, Sansavini $G$, et al. Heterogeneous genetic alterations in sporadic nephrotic syndrome associate with resistance to immunosuppression. J Am Soc Nephrol. 2015;26(1):230-6. https://doi.org/10.1681/ASN.2013111155 PMid:25060053

27. Gat-Yablonski G, Phillip M. Nutritionally induced catch-up growth. Nutrients. 2015;7(1):517-51. https://doi.org/10.3390/ nu7010517

PMid:25594438

28. Rees L, Shroff R. The demise of calcium-based phosphate binders-is this appropriate for children? Pediatr Nephrol. 2015;30(12):2061-71. https://doi.org/10.1007/ s00467-014-3017-y
PMid:25543193

29. Kurella TM, Vittinghoff E, Yang J, Go AS, Seliger SL, Kusek JW, et al. Anemia and risk for cognitive decline in chronic kidney disease. BMC Nephrol. 2016;17:13. https://doi.org/10.1186/ s12882-016-0226-6

PMid:26823182

30. Ratcliffe LE, Thomas W, Glen J, Padhi S, Pordes BA, Wonderling $\mathrm{D}$, et al. Diagnosis and management of iron deficiency in CKD: A summary of the NICE guideline recommendations and their rationale. Am J Kidney Dis. 2016;67(4):548-58. https:// doi.org/10.1053/j.ajkd.2015.11.012 PMid:26763385

31. Safina Al. Clinical and Pathogenetic Role of Bacterial and Vira Infections in the Development and Progression of Pyelonephritis in Children, Nizhny Novgorod; 2005.

32. Safina AI, Daminova MA. Acute renal failure in newborns. Prakticheskaja Med. 2011;5(53):43-50.

33. Safina AI, Lutfullin IJ, Gajnullina JE, Galeeva AV. The metabolic syndrome in children and adolescents as a complex risk factor for cardiovascular disease. Prakticheskaja Med. 2010;5(44):61-5. 